\title{
TrgI, toluene repressed gene I, a novel gene involved in toluene-tolerance in Pseudomonas putida S12
}

\author{
Rita J. M. Volkers $\cdot$ Hendrik Ballerstedt $\cdot$ \\ Harald Ruijssenaars · Jan A. M. de Bont • \\ Johannes H. de Winde $\cdot$ Jan Wery
}

Received: 14 July 2008/Accepted: 25 November 2008/Published online: 17 December 2008

(C) Springer 2008

\begin{abstract}
Pseudomonas putida S12 is well known for its remarkable solvent tolerance. Transcriptomics analysis of this bacterium grown in toluene-containing chemostats revealed the differential expression of 253 genes. As expected, the genes encoding one of the major solvent tolerance mechanisms, the solvent efflux pump SrpABC and its regulatory genes $\operatorname{srpRS}$ were heavily up-regulated. The increased energy demand brought about by toluene stress
\end{abstract}

Communicated by T. Matsunaga.

Electronic supplementary material The online version of this article (doi:10.1007/s00792-008-0216-0) contains supplementary material, which is available to authorized users.

R. J. M. Volkers $(\bowtie) \cdot H$. Ballerstedt $\cdot$ H. Ruijssenaars ·

J. A. M. de Bont · J. Wery

TNO Quality of Life, P.O. Box 5057,

2600 GB Delft, The Netherlands

e-mail: rita.volkers@tno.nl

J. H. de Winde

Department of Biotechnology,

Delft University of Technology, Julianalaan 67,

2628 BC Delft, The Netherlands

R. J. M. Volkers · H. Ballerstedt · H. Ruijssenaars ·

J. A. M. de Bont · J. H. de Winde · J. Wery

Kluyver Centre for Genomics of Industrial Fermentation,

Julianalaan 67, 2628 BC Delft, The Netherlands

Present Address:

J. A. M. de Bont

Royal Nedalco, P.O. Box 6,

4600 AA Bergen op Zoom, The Netherlands

Present Address:

J. Wery

Dyadic Nederland BV, Nieuwe Kanaal 7S,

6709 PA Wageningen, The Netherlands was also reflected in transcriptional changes: genes involved in sugar storage were down-regulated whereas genes involved in energy generation such as isocitrate dehydrogenase and NADH dehydrogenases, were up-regulated in the presence of toluene. Several flagella-related genes were upregulated and a large group of transport genes were downregulated. In addition, a novel Pseudomonas-specific gene was identified to be involved in toluene tolerance of $P$. putida S12. This toluene-repressed gene, $\operatorname{trgI}$, was heavily downregulated immediately upon toluene exposure in batch cultures. The relationship of $\operatorname{trgI}$ with solvent tolerance was confirmed by the increased resistance to toluene shock and toluene induced lysis of $\operatorname{trg} I$ knock-out mutants. We propose that down-regulation of $\operatorname{trgI}$ plays a role in the first line of defence against solvents.

Keywords Pseudomonas putida S12 - Solvent-tolerance · Toluene $\cdot \operatorname{trgI} \cdot$ Transcriptomics

\section{Introduction}

The solvent-tolerant bacterium Pseudomonas putida $\mathrm{S} 12$ is quite exceptional in its ability to withstand a wide range of toxic organic solvents such as toluene and benzene, in concentrations that are lethal to most microorganisms (Isken and de Bont 1998; Kieboom and de Bont 2000; Ramos et al. 2002). Organic solvents accumulate in lipid membranes of living cells, causing an increase of the membrane fluidity and a decrease of bilayer stability (Sikkema et al. 1995; Weber and de Bont 1996). A major adverse effect of solvent accumulation is the dissipation of the proton motive force (PMF) by a passive flux of protons across the cell membrane. Also the functioning of membrane-embedded proteins is compromised as their 
interaction with the membrane lipids is affected (Sikkema et al. 1995). Three types of membrane-associated solvent tolerance mechanisms have been elucidated (Heipieper and de Bont 1994; Weber and de Bont 1996; Ramos et al. 1997; Isken and de Bont 1998; Kieboom and de Bont 2000; Ramos et al. 2002): (1) cytoplasmic membrane changes, (2) outer membrane changes, and (3) active efflux of organic solvents. All three modes of solvent tolerance have been found in solvent-tolerant Pseudomonads, but it is likely that additional mechanisms exist. Moreover, several cross-relations may exist between these protective mechanisms.

Recently, we reported the proteomics analysis of toluene-affected chemostat-grown P. putida S12 (Volkers et al. 2006). This and another recent proteomics study on $P$. putida DOT-T1E (Segura et al. 2005) yielded valuable information with regard to the toluene response at the protein level, e.g. the observation that a number of tricarboxylic acid (TCA) cycle enzymes were upregulated. In addition to these proteomics studies, a number of transcriptomics studies have been carried out on several organisms exposed to different organic solvents (Hayashi et al. 2003; Fujita et al. 2004; Matsui et al. 2006). In yeast, the genes involved in isooctane tolerance were found to be constitutively expressed rather than being induced by the solvent (Matsui et al. 2006). Fujita et al. (2004) mainly confirmed previous insights into the tolerance of yeast to straight-chain alcohols and hydrocarbons like, e.g. the involvement of genes associated with cell growth inhibition and morphological changes. In E. coli six genes related to hexane tolerance were identified with transcriptomics and tested in overexpression mutants (Hayashi et al. 2003). Only overexpression of MarA led to increased solvent tolerance, which confirmed earlier observations that this gene is involved in solvent tolerance. Dominguez-Cuevas et al. (2006) assessed the transcriptional response of $P$. putida KT2440[pWW0] to a shock treatment with toluene, $o$-xylene and 3-methylbenzoate in batch cultures. They concluded that this toluene-degrading strain responds to toluene as a stressor rather than a nutrient. Several recent studies furthermore combine transcriptomics and proteomics analyses. In most cases, the two -omics technologies were used supplementarily to each other yielding a panoramic view of the responses of the organism to various conditions (Griffin et al. 2002; Mostertz et al. 2004; Brown et al. 2006; Budde et al. 2006).

The aim of the present study was to gain further insight into the solvent tolerance mechanisms of $P$. putida $\mathrm{S} 12$, in addition to results from our previous proteomics study (Volkers et al. 2006). Our finding that the hypothetical protein PP3611 was down-regulated (Volkers et al. 2006) was confirmed at the transcriptional level. We furthermore established the relationship between PP3611, renamed
TrgI, and toluene tolerance and present evidence that the down-regulation of $\operatorname{TrgI}$ is part of the first line of defence against toluene in P. putida S12.

\section{Materials and methods}

\section{Bacterial strains and plasmids}

The bacterial strains and plasmids used in this study are shown in Table 1. P. putida S12 was originally isolated as a styrene utilising bacterium (Hartmans et al. 1989). The expression vectors pJTTtrgI and $\mathrm{pJNN} \operatorname{trgI}(\mathrm{t})$ were constructed as follows: oligonucleotides $5^{\prime}$-GCGGCGG CCGCGTCAGCGCGAGGTTTCG-3' (forward) and $\overline{5^{\prime}-\mathrm{CG}}$ CGAATTCCTATGAACCCCATTCGTAC-3' (reverse) were designed based on the published sequence of P. putida KT2440 PP3611 (GenBank accession no. NC_002947) including restriction sites for cloning in the expression vectors pJTTmcs (Nijkamp et al. 2007) and pJNNmcs(t) (Nijkamp et al. 2005). The vectors and the PCR-amplified $\operatorname{trgI}$ were restricted with $N o t \mathrm{I}$ and EcoRI. Ligation of $\operatorname{trgI}$ into the vectors yielded plasmids pJTTtrgI and $\mathrm{pJNN} \operatorname{trgI}(\mathrm{t})$. P. putida $\mathrm{S} 12$ was transformed with pJTTtrgI, resulting in $P$. putida S12ptrgI. The knockout mutant $P$. putida S12 $\Delta \operatorname{trgI}$ was constructed as follows: oligonucleotides 5'-CGCGGATCCGCTGCACGCACCC ATCC-3' (forward), 5'-CGCTCTAGAGAAAGCGACTG AAGAGTCC- $3^{\prime}$ (reverse), $5^{\prime}$-CGCTCTAGACGTGTCA CGTAGATGTCG-3' (forward) and $5^{\prime}$-CGCGCGG CCGCCGACACGCTCGATGTTGG- $3^{\prime}$ (reverse) were designed on the published sequence of $P$. putida KT2440 (GenBank accession no. NC_002947) including restriction sites (BamHI, XbaI, XbaI and NotI, respectively) for cloning of $\operatorname{trgI}$, in two parts and with flanking sequences (the fragments had a total length of $1 \mathrm{~kb}$ ), in the suicide vector pJQ200SK (Quandt and Hynes 1993). The tetracycline resistance gene tetA was cloned into the XbaI site of the resulting plasmid yielding pJQtrgI. After transforming pJQtrgI to $P$. putida S12 and subsequent selection on tetracycline and gentamicin-containing medium, a mutant with the interrupted $\operatorname{trgI}$ gene stably integrated in the genome was obtained: $P$. putida S12 $\Delta$ trgI. The knock-out mutants $P$. putida S12 $\Delta$ pyrR and $P$. putida $\mathrm{S} 12 \Delta$ at were constructed analogously to $P$. putida S12 $\Delta \operatorname{trgI}$. Oligonucleotides used for construction of $S 12 \Delta$ pyrR were 5'-CCGGGATCCGCTGACCACGTCACAGG-3' (forward), 5'-GGCTCTAGACCTTCGACCTCGAACGG-3' (reverse), 5'-CCGTCTAGAAACTGTTCGATTACGGC CG-3' (forward) and 5'-GGCGCGGCCGCGATGGCG TCAGGCTTGG- $3^{\prime}$ (reverse). Oligonucleotides used for construction of $P$. putida S12 $\Delta$ at were $5^{\prime}$-GCGTCTAGA TCGGCGATGAAGGCCGCGAC-3' (forward), $\quad 5^{\prime}-\mathrm{G}$ 
Table 1 Bacterial strains and plasmids used in this study

\begin{tabular}{|c|c|c|}
\hline & Characteristics & Source or reference \\
\hline \multicolumn{3}{|l|}{ Strains } \\
\hline P. putida $\mathrm{S} 12$ & Wild type & Hartmans et al. (1990) \\
\hline P. putida $\mathrm{S} 12 \mathrm{ptrgI}$ & $\begin{array}{l}\text { P. putida } \mathrm{S} 12 \text { with plasmid } \\
\text { pJTTtrgI, } \mathrm{Gm}^{\mathrm{R}}\end{array}$ & This study \\
\hline P. putida $\mathrm{S} 12 \Delta \operatorname{trgI}$ & P. putida $\mathrm{S} 12$ with interrupted $\operatorname{trg} I$ & This study \\
\hline P. putida $\mathrm{S} 12 \Delta \mathrm{pyrR}$ & $\begin{array}{l}\text { P. putida } \mathrm{S} 12 \text { with interrupted } \\
\text { pyrR }\end{array}$ & This study \\
\hline P. putida $\mathrm{S} 12 \Delta$ at & $\begin{array}{l}\text { P. putida } \mathrm{S} 12 \text { with interrupted } \\
\text { aminotransferase }\end{array}$ & This study \\
\hline \multicolumn{3}{|l|}{ Plasmids } \\
\hline $\begin{array}{l}\text { pJTTmcs (formerly } \\
\text { named pTac) }\end{array}$ & $\begin{array}{l}\text { Expression vector with } \\
\text { constitutively expressed tac } \\
\text { promotor, } \mathrm{Gm}^{\mathrm{R}}, \mathrm{Amp}^{\mathrm{R}}\end{array}$ & Nijkamp et al. (2007) \\
\hline pJNNmcs $(t)$ & $\begin{array}{l}\text { Expression vector with inducible } \\
\text { promoter nagAa }\end{array}$ & Wierckx et al. (2008) \\
\hline pJQ200SK & Suicide vector, $\mathrm{Gm}^{\mathrm{R}}$ & Quandt and Hynes (1993) \\
\hline pJTTtrgI & $\begin{array}{l}\text { Expression vector pJTT with trgI, } \\
\mathrm{Gm}^{\mathrm{R}}, \mathrm{Amp}^{\mathrm{R}}\end{array}$ & This study \\
\hline $\mathrm{pJNN} \operatorname{trg} I(\mathrm{t})$ & $\begin{array}{l}\text { Expression vector pJNNmcs(t) } \\
\text { with } \operatorname{trgI}, \mathrm{Gm}^{\mathrm{R}}\end{array}$ & This study \\
\hline pJQtrgI & $\begin{array}{l}\text { pJQ200SK containing interrupted } \\
\text { trgI }\end{array}$ & This study \\
\hline
\end{tabular}

CGGCGGCCGCGCCGCCAGCCTACTGTGTGG-3' (reverse), 5'-GCGGGATCCGATGTAGTCCGACCAGTT ATAG-3' (forward) and 5'-GCGTCTAGAAAGGTGAAG GAGATCCTCGCC-3' (reverse).

\section{Culture conditions}

Mineral salts medium (MM) (Hartmans et al. 1989) was used as the standard culturing medium, with the following modifications: $37 \mathrm{mM}$ K-phosphate, $1.5 \mathrm{mM}$ $\mathrm{Na}_{2} \mathrm{SO}_{4}$ as the sulphur source, $\mathrm{NH}_{4} \mathrm{Cl}$ as the nitrogen source and glucose as the carbon source. P. putida was cultured at $30^{\circ} \mathrm{C} ;$ E. coli at $37^{\circ} \mathrm{C}$. For culturing under carbon limitation, $10 \mathrm{mM}$ glucose and $30 \mathrm{mM} \mathrm{NH} \mathrm{Nl}_{4} \mathrm{Cl}$ $(\mathrm{C}: \mathrm{N}=2: 1)$ were added to $\mathrm{MM}$. For culturing under nitrogen limitation $\mathrm{MM}$ contained $44 \mathrm{mM}$ glucose and $4 \mathrm{mM} \mathrm{NH} \mathrm{NH}_{4} \mathrm{Cl}(\mathrm{C}: \mathrm{N}=66: 1)$. Luria-Bertani broth (LB) (Sambrook et al. 1982) was used with $1.5 \%$ (w/v) agar as a solid medium. Batch cultivation was carried out in 250-ml Erlenmeyer flasks containing $50 \mathrm{ml}$ of liquid medium, placed on a horizontally shaking incubator. Batch cultivation with toluene was carried out in $250 \mathrm{ml}$ airtight Boston bottles with Mininert valves (Alltech, Deerfield, IL, USA) containing $10 \mathrm{ml}$ LB medium. Toluene shocks were applied to cells growing exponentially in LB medium (optical density at $600 \mathrm{~nm}$ of $0.8-1.0$ ) by incubating for $30 \mathrm{~min}$ with a second phase of toluene $(1 \%(\mathrm{v} / \mathrm{v}))$.
The survival frequency was determined by counting the number of colony-forming units before and after the toluene shock. Dilutions of the cultures made in $0.9 \%(w / v)$ saline were plated on agar plates by drop-plating. Per dilution, 5 drops of $10 \mu \mathrm{l}$ were applied on the plates. After drying, the plates were incubated for $18 \mathrm{~h}$ and the colonies were counted in the drops that contained separate colonies.

Continuous culturing in the presence and in the absence of toluene under nitrogen- and carbon-limitation was performed in chemostats (BioFloIIc, New Brunswick Scientific, Edison, NJ, USA) with a working volume of 1.01 , at $\mathrm{pH} 7.0$, a stirring speed of $350 \mathrm{rpm}$, and a dilution rate of $0.2 \mathrm{~h}^{-1}$. Pure oxygen was supplied at $5 \mathrm{ml} / \mathrm{min}$. Toluene was added separately with a KD Scientific syringe pump (Applikon, Schiedam, The Netherlands) to final concentrations of 3 and $5 \mathrm{mM}$. The chemostats were inoculated with a $50-\mathrm{ml}$ culture growing at mid-log growth rate. Samples for transcriptomics analysis and determination of glucose, gluconate, 2-ketogluconate and ammonium concentrations were drawn at steady state, which was reached after five volume changes, as was confirmed by cell density measurements. After sampling the culture without toluene, toluene was added to $3 \mathrm{mM}$ and samples were drawn after the next steady state had been reached. Subsequently, toluene was added to $5 \mathrm{mM}$ and sampling was performed again at steady state. Culturing was performed in duplicate and each steady state was sampled once, resulting in 12 microarrays, two per toluene concentration. 
Culturing in the presence of a concentration series of antibiotics was carried out in 96-wells plates. Ten microliter of an exponentially growing culture was added to $90 \mu \mathrm{l}$ of LB medium supplemented with antibiotic. Growth was assessed by visual inspection after 1, 2 and 5 days. MIC (minimal inhibiting concentration) was defined as the antibiotic concentration at which no growth was observed.

\section{Transcriptomics analysis}

Sampling, mRNA isolation and cDNA preparation for transcriptomics analysis were performed as described previously (Wierckx et al. 2008). In brief, 1-ml culture samples were quenched in $1 \mathrm{ml}$ ice-cold methanol, centrifuged and $1 \mathrm{ml}$ RNAlater (Ambion, Foster City, CA, USA) was applied to prevent RNA degradation. Pellets were flash frozen in liquid nitrogen and stored at $-80^{\circ} \mathrm{C}$. Total RNA was isolated using the RNeasy Mini Purification Kit (Qiagen, Hilden, Germany). mRNA was isolated using the MICROBExpress Bacterial mRNA Purification Kit (Ambion). Random priming, cDNA synthesis, purification and labelling were performed according to the microarray manufacturer's instructions (Affymetrix, Santa Clara, CA, USA). The custom high-density microarrays used were based on the genome of $P$. putida KT2440, which has $81.8 \%$ similarity on the gene level with $P$. putida $\mathrm{S} 12$, with additional probe sets based on known sequences of P. putida S12 and related strains (Ballerstedt et al. 2007; Wierckx et al. 2008). Hybridisation was performed according to the manufacturer's instructions. Scanning of the microarrays was carried out by ServiceXS (Leiden, The Netherlands) on a high resolution Gene Chip Scanner 3000 7G system with autoloader (Affymetrix) using standard default analysis settings (filter: $570 \mathrm{~nm}$; pixel size: $2,5 \mu \mathrm{m})$.

Data analysis

Microarray data were imported into the GeneSpring GX 7.3.1 software package (Agilent Technologies, Santa Clara, CA, USA) using the GC RMA algorithm. After normalisation (signals below 0.01 were taken as 0.01 ; per chip: normalise to 50th percentile; per gene: normalise to median) of the data, probesets representing intergenic regions and control genes were removed, as well as nonchanging genes (between 0.667- and 1.334-fold change). On the resulting set of 995 differentially expressed genes a 2-way ANOVA test was applied, including a Benjamini and Hochberg false discovery rate test with a $P$ value cutoff of 0.03 in order to identify the genes that were differentially expressed exclusively as a consequence of the presence of toluene. The two conditions varied were toluene concentration $(0,3$ and $5 \mathrm{mM})$ and nutrient limitation (nitrogen- and carbon-limitation). The genes that were designated as differentially expressed as a result of variation in the toluene concentration were divided into two groups, one with up-regulated genes and one with downregulated genes.

\section{Analytical methods}

Cell densities were measured at $600 \mathrm{~nm}$ with a WPA CO800 Biowave Cell Density Meter (Biochrom, Cambridge, UK). Glucose, gluconate, 2-keto-gluconate and ammonium concentrations were determined as described previously (Nijkamp et al. 2005). The biomass yield was determined by calculating the amount of protein produced per amount of glucose consumed. An optical density of 1 at $600 \mathrm{~nm}$ corresponds to a concentration of cell dry weight of 465 and $279 \mathrm{mg} / \mathrm{l}$ protein (data not shown).

qPCR-Analysis

Total RNA extractions were performed with the RNeasy kit, as described by the manufacturer (Qiagen). After DNase treatment, the RNA samples were treated with the RNeasy MiniElute (Qiagen) clean-up kit. RNA-concentrations were measured using a NanoDrop-1000 spectrophotometer (Thermo Scientific, Waltham, MA, USA). All primers (Table 2) were purchased from Eurofins MWG Operon (Ebersberg, Germany). Targets for q-RTPCR and qPCR were the genes and corresponding mRNAs
Table 2 Primers used for qPCR analysis

\begin{tabular}{lllc}
\hline Target gene & Primer & Nucleotidic sequence $\left(5^{\prime} \rightarrow 3^{\prime}\right)$ & Amplicon size \\
\hline trgI & PP3611_A_f & ATGTCACCACACAGGTAACG & 79 \\
& PP3611_A_r & ACATCCTTCTTCTCGTCAGG & \\
srpB & srpB_B_f & ATCTGCTGGAAACCGTAGAC & 174 \\
& srpB_A_r & ACATGACCAGGAAGACCAGT & \\
plsB & PP1520_A_f & GACTACCTGCTGCTGTCGTA & 182 \\
& PP1520_A_r & TGCAGGTACTCGTTGAACAC & \\
paaI & PP3281_B_f & CTGCACCATCGACTACCTG & 198 \\
& PP3281_B_r & CATTCATCTTGCGTCTCCTG & \\
\hline
\end{tabular}


coding for $\operatorname{trg} I, \operatorname{srp} B$ and putative $p l s B$ and paa. The latter two genes are housekeeping-genes used as a control to correct for mRNA losses during RNA-preparation and for experimental variations. They were selected after transcriptomics analysis under comparable experimental conditions in which constant gene expression was found. Specific primers (Table 2) were designed using Primer3software (http://fokker.wi.mit.edu/primer3/input-040.htm; length max. 20 bases, G/C content $50-60 \%, T_{\mathrm{m}} 55-60^{\circ} \mathrm{C}$ ). PCR-primer target sequences were chosen to achieve amplicon lengths of $75-200 \mathrm{bp}$. To predict possible amplicon secondary structures Mfold software (http:// www.bioinfo.rpi.edu/applications/ mfold/) was used. qPCR was performed with a spectrofluorimetric thermal cycler (iCycler thermal cycler equipped with optical module; BioRad, Hercules, CA, USA) using iQ SYBR Green Supermix for qPCR or iScript One-Step RT-PCR Kit with SYBR Green for q-RT-PCR (BioRad) of total RNA samples in 96-well plates according to manufacturers' protocols $\left(T_{\text {annealing: }}: 58^{\circ} \mathrm{C}\right)$. Ribonuclease inhibitor Superase-In (Ambion) was added at a concentration of $0.5 \mathrm{U} / \mu \mathrm{l}$ to all q-RT-PCR batches. Fluorescence of ds-DNA-bound SYBR Green was measured at the end of each polymerisation step. A denaturation curve $\left(55-95^{\circ} \mathrm{C}, 0.05^{\circ} \mathrm{C} \mathrm{s}^{-1}\right)$ specific for each amplified sequence was established at the end of the PCR reaction. The increment in fluorescence versus reaction cycle was plotted and the threshold cycle $\left(C_{\mathrm{T}}\right)$ was obtained by manual positioning of the threshold baseline at 100 relative fluorescence units. Calibration curves relating the $C_{\mathrm{T}}$ as function of log of copy number of target gene were established using tenfold serial dilutions of $P$. putida $\mathrm{S} 12$ genomic DNA or plasmid DNA carrying either a cloned $\operatorname{trgI-}$ or $\operatorname{srpB}$ gene, respectively. Standard curves spanned a range of $10-10^{7}$ gene copies per $\mu l$ of template DNA. Efficiencies of PCR amplifications were approximately $95 \%$. All absolute quantifications were obtained using iCycler iQ real-time detection system software version 3.0 (BioRad). The $C_{\mathrm{T}}$ of individual $\operatorname{trgI}$ and $\operatorname{srp} B$ measurements were normalized by average factors $(0.97-1.02)$ calculated from differences in copy numbers of transcripts of the housekeeping genes in different samples to a constant value.

\section{Results}

Toluene exposure has a modest effect on global gene expression as compared to nutrient limitation

Different nutrient limitations have a dramatic effect on global gene expression as has been shown, e.g. Saccharomyces cerevisiae (Boer et al. 2003; Wu et al. 2004) and E. coli (Hua et al. 2004). This phenomenon should be considered when studying the effects of a chemical effector such as toluene at the transcriptome level. Therefore, we chose to monitor the effect of 0.3 and $5 \mathrm{mM}$ toluene on the transcriptome of $P$. putida $\mathrm{S} 12$ both in nitrogen and carbon limited chemostat cultures. This setup allowed for the identification of transcriptional responses specific to toluene exposure irrespective of the nutrient limitation as the noise caused by nutrient limitations can be filtered out from the data. Five $\mathrm{mM}$ of toluene is near water saturation and $3 \mathrm{mM}$ of toluene is just above the threshold that triggers the adaptational responses of the organism to toluene (Kieboom et al. 1998a). The transcriptomes were analysed using custom Affymetrix high-density microarrays (Ballerstedt et al. 2007).

The effect of the culture conditions on global gene expression was determined by principal component analysis (PCA) (Fig. 1a). All genes on the array were included in the calculation, and the values are the average of two microarrays. The plot shows that the distance between the "N-limited" microarrays and the "C-limited" microarrays was much larger than the distances between the microarrays from the cultures with and without toluene. This confirmed that the effect of different nutrient limitations on global gene expression is larger than the effect of the presence of toluene. The residual concentration of glucose and nitrogen in the steady state cultures of $P$. putida S12 was similar to the previous study (Volkers et al. 2006), the decrease in the biomass yield in the presence of toluene (data not shown) was comparable to earlier findings (Isken

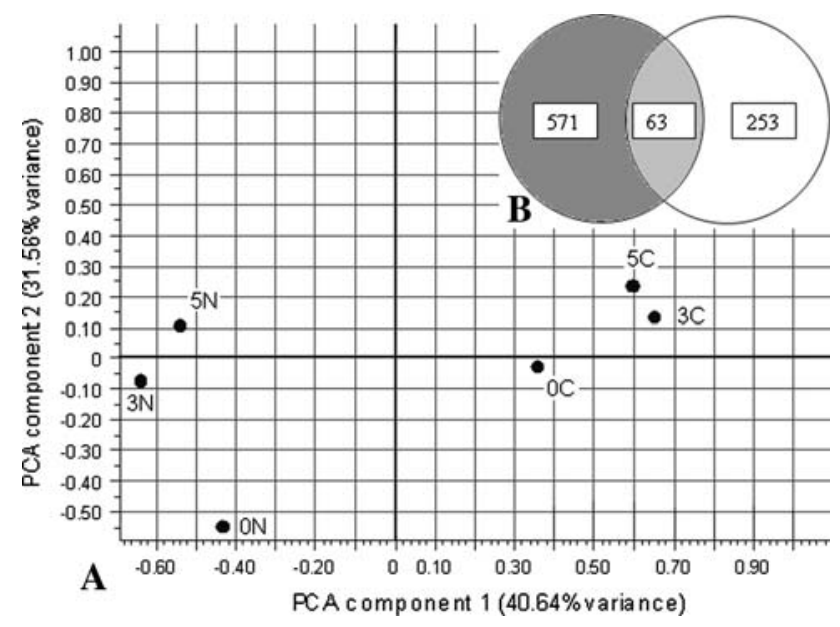

Fig. 1 a Principle component analysis (PCA) of global gene expression profiles on the following conditions: mineral salts medium with carbon limitation $(C)$; mineral salts medium with nitrogen limitation $(N)$; $0 \mathrm{mM}$ toluene, $3 \mathrm{mM}$ toluene, $5 \mathrm{mM}$ toluene $(0,3,5)$. Values are the average of two microarrays). b Venn diagram of 2-way ANOVA results. Dark grey genes differentially expressed because of nutrient limitation; white genes differentially expressed because of toluene concentration; light grey genes differentially expressed because of interaction between nutrient limitation and toluene concentration 
et al. 1999). The biomass yield in the presence of $3 \mathrm{mM}$ toluene was equal to the biomass yield in the presence of $5 \mathrm{mM}$ toluene.

The genes that were differentially expressed in response to toluene, independent of the nutrient limitation, were identified using a 2-way ANOVA test (Tables 3, 4 and "Materials and methods"). The conditions used in the calculation were 'nutrient limitation' and 'toluene concentration'. The group of genes that were differentially expressed because of variation in the nutrient limitation comprised of 571 genes, whereas the group of genes that was differentially expressed because of variation in the toluene concentration contained 253 genes (Fig. 1b). The genes differentially expressed as a result of a nutrient limitation-dependent response on toluene formed a group of 63 genes. Thus, more than twice as many genes were differentially expressed as a result of nutrient limitation than as a result of toluene concentration. These results were in good agreement with the results from the PCA (Fig. 1).

Identification of differentially expressed genes in the presence of toluene

A total of 253 genes were differentially expressed solely as a result of variation of the toluene concentration. In this group, 85 genes were up-regulated (34\%) and 168 genes were down-regulated (66\%). In Tables 3 and 4 the genes in the most relevant functional categories, based on a previously conducted proteomics experiment, are shown (Volkers et al. 2006). Transport genes are interesting because one of the solvent-tolerance mechanisms comprises the active efflux of solvent molecules. Because solvents have a high impact on the membrane and the energy-household, these categories are also shown. The complete list of genes is presented as supplementary material (S1). Genes are sorted by predicted function and their probable relation with solvent tolerance.

The defence against solvents is highly energy demanding (Isken et al. 1999; Segura et al. 2005; Volkers et al. 2006). The upregulation of several NADH dehydrogenase subunits in the presence of toluene is in agreement with this observation. In addition, a TCA cycle gene was up-regulated: isocitrate dehydrogenase, which was also found in our proteomic study (Volkers et al. 2006). In contrast, two other TCA cycle genes were down-regulated: fumC-II and $a c n A$. However, since the primary metabolism is regulated at various levels, this result must be looked upon cautiously. The upregulation of genes encoding several cytochrome $o$ ubiquinol oxidase subunits can be interpreted as an energy-effect as well, although $c y o C$ has also been suggested to play a role in cell surface hydrophobicity (Kobayashi et al. 1999). The transcript levels of genes associated with the storage of sugars, for example encoding glycogen synthase, are down-regulated in the presence of toluene, both under $\mathrm{N}$ - and $\mathrm{C}$-limitation. At the same time, the glucono- and 2-ketogluconate-kinases and -transporters were up-regulated. These observations are indicative of an increased rate of sugar consumption and decreased sugar storage under solvent stress.

Since solvents primarily affect the integrity of the cellular membranes, genes relating to membrane-associated functions and outer cell structures were envisaged to be more than averagely represented among the differentially expressed proteins in the toluene-challenged chemostats. As expected, the genes encoding the tripartite solvent efflux pump SrpABC were up-regulated, together with their regulatory genes $\operatorname{srpR}$ and $\operatorname{srpS}$. SrpABC is the only RND-family transporter that was up-regulated. Three ompA-like genes, expectedly encoding outer membrane proteins, were down-regulated. In addition, five flagellaassociated genes were found to be up-regulated, whereas five pili-related genes were down-regulated. Two transglycosylases, $\quad N$-acetylmuramoyl-L-amidase and a penicillin-binding protein, all involved in the biosynthesis of the peptidoglycan cell wall, were up-regulated under toluene stress.

Although toluene clearly is a stressor, only two general stress response genes were up-regulated, encoding HtpX, a heat shock protein and FlkB-1, peptidyl-prolyl cis-trans isomerase (FKBP-type). CspD, a cold shock protein, was down-regulated.

The Pseudomonas-specific hypothetical gene PP3611, renamed $\operatorname{trgI}$, is down-regulated in the presence of toluene

The hypothetical gene corresponding to locus PP3611 in the $P$. putida KT2440 genome was found to be downregulated in this study, in agreement with our previously published proteomics analysis of $P$. putida S12 grown in the presence of toluene (Volkers et al. 2006). Since the gene is repressed in response to toluene, we renamed it toluene repressed gene I, or $\operatorname{trg} I$. Nucleotide sequencing confirmed that $\operatorname{trg} I$ in $P$. putida S12 was $>98 \%$ identical to PP3611 of P. putida KT2440. Eight nucleotides differed, resulting in a single amino acid change in residue 61 (aspartate in strain S12 and glutamate in strain KT2440). Sequencing of the region around trgI showed that the genomic organization of $\operatorname{trgI}$ and its neighbouring genes in $P$. putida $\mathrm{S} 12$ is identical to $P$. putida KT2440 (data not shown). The genes directly upstream (a putative TonBdependent receptor) and downstream (a hypothetical gene) of $\operatorname{trgI}$ are transcribed in the opposite direction. There are no indications that $\operatorname{trgI}$ is part of an operon.

$\operatorname{TrgI}$ is a relatively small protein consisting of 193 amino acids. Protein BLAST analysis (http://www.ncbi.nlm. 
Table 3 Genes that are up-regulated in P. putida S12 in the presence of 3 and $5 \mathrm{mM}$ toluene

\begin{tabular}{|c|c|c|c|c|c|}
\hline Locus tag $^{\mathrm{a}}$ & Gene name & Description $^{\mathrm{e}}$ & $\begin{array}{l}\text { Ratio }^{\mathrm{c}} 3 \mathrm{mM} \\
\text { toluene/no toluene }\end{array}$ & $\begin{array}{l}\text { Ratio }^{\mathrm{c}} 5 \mathrm{mM} \\
\text { toluene/no toluene }\end{array}$ & $\mathrm{N} / \mathrm{C} / \mathrm{D}^{\mathrm{d}}$ \\
\hline \multicolumn{6}{|l|}{ Energy } \\
\hline PP0626 & $\mathrm{Ndh}$ & NADH dehydrogenase & 1.36 & 2 & $\mathrm{~N}$ \\
\hline PP0812 & CуоА & $\begin{array}{l}\text { Cytochrome o ubiquinol oxidase, } \\
\text { subunit II }\end{array}$ & 1.97 & 2.05 & $N / D^{f}$ \\
\hline PP0813 & CyoB & $\begin{array}{l}\text { Cytochrome o ubiquinol oxidase, } \\
\text { subunit I }\end{array}$ & 2.1 & 2.16 & $N / D^{f}$ \\
\hline PP0814 & CyoC & $\begin{array}{l}\text { Cytochrome o ubiquinol oxidase, } \\
\text { subunit III }\end{array}$ & 2.01 & 1.94 & $\mathrm{~N} / \mathrm{D}^{\mathrm{f}}$ \\
\hline PP0815 & CyoD & $\begin{array}{l}\text { Cytochrome o ubiquinol oxidase, } \\
\text { protein CyoD }\end{array}$ & 1.93 & 2.05 & $N / D^{f}$ \\
\hline PP0816 & CyoE & Protoheme IX farnesyltransferase & 2.08 & 2.25 & $N / D^{f}$ \\
\hline PP3377 & & 2-Ketogluconate transporter, putative & 4.59 & 6.59 & $\mathrm{~N}$ \\
\hline PP3378 & KguK & 2-Ketogluconate kinase & 3.98 & 5.69 & $\mathrm{~N}$ \\
\hline PP3416 & GnuK & Gluconokinase & 2.61 & 4.19 & $\mathrm{~N}$ \\
\hline PP3417 & GntP & Gluconate transporter & 2.33 & 3.48 & $\mathrm{~N}$ \\
\hline PP4012 & & $\begin{array}{l}\text { Isocitrate dehydrogenase, NADP- } \\
\text { dependent, monomeric-type }\end{array}$ & 2.22 & 2.6 & $\mathrm{C}^{\mathrm{g}}$ \\
\hline PP4128 & NuoK & NADH dehydrogenase I, K subunit & 1.95 & 2.1 & $\mathrm{~N}$ \\
\hline PP4129 & NuoL & NADH dehydrogenase I, L subunit & 1.62 & 1.92 & $\mathrm{~N}$ \\
\hline PP4130 & NuoM & NADH dehydrogenase $\mathrm{I}, \mathrm{M}$ subunit & 1.85 & 1.82 & $\mathrm{~N}$ \\
\hline \multicolumn{6}{|l|}{ Transport } \\
\hline $\mathrm{AF} 029405^{\mathrm{b}}$ & SrpB & $\begin{array}{l}\text { Pseudomonas putida solvent } \\
\text { transporter gene, inner membrane } \\
\text { transporter protein }\end{array}$ & 10.42 & 10.8 & $\mathrm{~N}$ \\
\hline $\mathrm{AF} 029405^{\mathrm{b}}$ & SrpA & $\begin{array}{l}\text { Pseudomonas putida solvent } \\
\text { transporter gene, periplasmic linker } \\
\text { protein }\end{array}$ & 13.35 & 13.6 & $\mathrm{~N}$ \\
\hline $\mathrm{AF} 029405^{\mathrm{b}}$ & SrpC & $\begin{array}{l}\text { Pseudomonas putida solvent } \\
\text { transporter gene, outer membrane } \\
\text { channel protein }\end{array}$ & 10.75 & 10.95 & $\mathrm{~N}$ \\
\hline $\mathrm{AF} 029405^{\mathrm{b}}$ & SrpR & $\begin{array}{l}\text { Pseudomonas putida solvent } \\
\text { transporter gene, regulatory gene }\end{array}$ & 6.46 & 6.68 & $\mathrm{~N}$ \\
\hline $\mathrm{AF} 029405^{\mathrm{b}}$ & SrpS & $\begin{array}{l}\text { Pseudomonas putida solvent } \\
\text { transporter gene, regulatory gene }\end{array}$ & 10.19 & 10.99 & $\mathrm{~N}$ \\
\hline PP0113 & & $\mathrm{ABC}$ transporter, permease protein & 1.53 & 1.48 & $\mathrm{~N}$ \\
\hline PP1272 & & $\begin{array}{l}\text { Multidrug efflux MFS membrane } \\
\text { fusion protein, putative }\end{array}$ & 2.36 & 2.76 & $\mathrm{~N}$ \\
\hline PP1743 & & $\begin{array}{l}\text { Sodium:solute symporter family } \\
\text { protein }\end{array}$ & 6.57 & 8.39 & $\mathrm{~N}$ \\
\hline PP4881 & & $\begin{array}{l}\text { Iron } \mathrm{ABC} \text { transporter, periplasmic } \\
\text { iron-binding protein, putative }\end{array}$ & 1.69 & 2.27 & $\mathrm{~N}$ \\
\hline PP5196 & & $\begin{array}{l}\text { Iron } \mathrm{ABC} \text { transporter, periplasmic } \\
\text { iron-binding protein, putative }\end{array}$ & 2.69 & 3.07 & $\mathrm{~N}$ \\
\hline PP5307 & ExbD & $\begin{array}{l}\text { Ferric siderophore transport system, } \\
\text { inner membrane protein ExbD }\end{array}$ & & 1.55 & 1.96 \\
\hline \multicolumn{6}{|l|}{ Membrane } \\
\hline PP1036 & & $\begin{array}{l}\text { Periplasmic binding domain } \\
\text { transglycosylase SLT domain } \\
\text { fusion protein }\end{array}$ & 1.46 & 1.58 & $\mathrm{~N}$ \\
\hline PP1871 & $\mathrm{HtpX}^{\mathrm{h}}$ & Heat shock protein HtpX & 1.69 & 2.27 & $\mathrm{~N}$ \\
\hline PP2244 & & Membrane protein, putative & 1.46 & 1.59 & $\mathrm{~N}$ \\
\hline PP4352 & FlhB & Flagellar biosynthetic protein FlhB & 1.49 & 1.43 & $\mathrm{~N}$ \\
\hline
\end{tabular}


Table 3 continued

\begin{tabular}{|c|c|c|c|c|c|}
\hline Locus tag $^{\mathrm{a}}$ & Gene name & Description $^{\mathrm{e}}$ & $\begin{array}{l}\text { Ratio }^{\mathrm{c}} 3 \mathrm{mM} \\
\text { toluene/no toluene }\end{array}$ & $\begin{array}{l}\text { Ratio }^{\mathrm{c}} 5 \mathrm{mM} \\
\text { toluene/no toluene }\end{array}$ & $\mathrm{N} / \mathrm{C} / \mathrm{D}^{\mathrm{d}}$ \\
\hline PP4354 & FliQ & Flagellar biosynthetic protein FliQ & 1.81 & 2 & $\mathrm{~N}$ \\
\hline PP4356 & FliO & Flagellar assembly protein FliO & 2.21 & 1.94 & $\mathrm{~N}$ \\
\hline PP4367 & FliH & Flagellar assembly protein FliH & 1.53 & 1.3 & $N / D^{f}$ \\
\hline PP4368 & FliG & Flagellar motor switch protein FliG & 2 & 1.88 & $\mathrm{~N}$ \\
\hline PP4805 & MltB & $\begin{array}{l}\text { Membrane-bound lytic murein } \\
\text { transglycosylase B }\end{array}$ & 2.1 & 2.03 & $\mathrm{~N}$ \\
\hline PP4897 & & $\mathrm{N}$-acetylmuramoyl-L-alanine amidase & 1.55 & 1.94 & $\mathrm{~N}$ \\
\hline PP5084 & & Penicillin-binding protein & 1.18 & 1.74 & $\mathrm{~N}$ \\
\hline \multicolumn{6}{|l|}{ Other } \\
\hline PP0684 & FlkB-1* & $\begin{array}{l}\text { Peptidyl-prolyl cis-trans isomerase, } \\
\text { FKBP-type }\end{array}$ & 1.4 & 1.98 & $\mathrm{~N}$ \\
\hline
\end{tabular}

${ }^{\text {a }}$ Locus tag based on genome of P. putida KT2440 (http://www.pseudomonas.com)

${ }^{b}$ NCBI database no

${ }^{c}$ Ratio of expression in 3 or $5 \mathrm{mM}$ toluene versus the absence of toluene

${ }^{d}$ New $(\mathrm{N})$, confirmatory $(\mathrm{C})$, discrepant (D) compared with results in relevant literature

e Description of genes based on locus tag description

${ }^{f}$ Refers to (Dominguez-Cuevas et al. 2006)

g Refers to (Volkers et al. 2006)

${ }^{\mathrm{h}}$ General stress response gene

nih.gov/BLAST/) indicated that TrgI is also present in $P$. putida F1 (99\% identity), P. putida GB-1 (90\% identity) and $P$. putida W619 (87\% identity). Also a relatively high percentage of identity with hypothetical proteins of other Pseudomonas species was found ( $P$. entomophila L48 (83\%), P. fluorescens PfO-1 (47\%) and P. fluorescens Pf-5 (46\%)). TrgI appears to be Pseudomonas-specific; the BLAST hits of proteins from other genera all scoring below $31 \%$ identity. SignalP in SMART (Schultz et al. 1998; Letunic et al. 2006) (http://smart.embl-heidelberg.de) identified a signal peptide in the first 26 amino acids (MNPIRTLARAVTLATLASAASFTVQA) of TrgI, which may suggest that TrgI is a periplasmic protein. No conserved domains were detected in TrgI (http://www.ncbi.nlm.nih. gov/Structure/cdd/ wrpsb.cgi), but a BLASTP2 search (http://dove.embl-heidelberg.de/Blast2/) showed that a 71-amino acid stretch (residues 40-110) has $29 \%$ identity with a transcription regulator of the MarR family. This family is involved in regulation of resistance to antibiotics, disinfectants and organic solvents, amongst other compounds. Many of the MarR-like regulators respond to aromatic compounds (Alekshun and Levy 1999).

$\operatorname{TrgI}$ is immediately down-regulated

after addition of toluene

Downregulation of $\operatorname{trgI}$ was observed in fully adapted, toluene-exposed steady state cultures. In order to establish the dynamic response of $\operatorname{trgI}$ to toluene, the expression profile of $\operatorname{trgI}$ was also studied in toluenechallenged batch cultures by qPCR analysis. In parallel, the expression profile of the solvent pump gene $\operatorname{srp} B$ was analysed. It has been shown in a previous study (Kieboom et al. 1998a) that $\operatorname{srp} B$ is maximally expressed up to several hours after toluene exposure and can therefore be considered a late response. Toluene $(5 \mathrm{mM})$ was added to an exponentially growing culture of $P$. putida $\mathrm{S} 12$ and timed samples were drawn for mRNA isolation. It was observed that transcription of $\operatorname{trgI}$ rapidly declined and reached a minimum after only 2 minutes upon addition of toluene (Fig. 2). At that time point, the transcription of $\operatorname{srp} B$ started to increase, reaching a maximum after $20 \mathrm{~min}$.

\section{Characterization of $\operatorname{trg} I$ knock-out and $\operatorname{trg} I$ overexpression mutants}

To further investigate the role of $\operatorname{trg} I$ in solvent tolerance and its possible mode of action, we constructed a $\operatorname{trg} I$ overexpression ( $P$. putida $\mathrm{S} 12$ ptrgI) and a trgI knock-out mutant ( $P$. putida $\mathrm{S} 12 \Delta \operatorname{trg} \mathrm{I})$ by disrupting the gene with a tetA marker. The trgI knockout strain appeared to be much more resistant to toluene-induced lysis than wildtype S12 and the $\operatorname{trgI}$ overexpression mutant. Although able to thrive in LB in the presence of $3 \mathrm{mM}$ toluene, the overexpression-mutant and wild-type S12 showed significant lysis whereas the $\operatorname{trgI-knockout~culture~showed~no~}$ cell lysis at all (Fig. 3). 
Table 4 Genes that are down-regulated in P. putida S12 in the presence of 3 and $5 \mathrm{mM}$ toluene

\begin{tabular}{|c|c|c|c|c|c|}
\hline Locus tag $^{\mathrm{a}}$ & Gene name & Description $^{\mathrm{e}}$ & $\begin{array}{l}\text { Ratio }^{\mathrm{c}} 3 \mathrm{mM} \\
\text { toluene/no toluene }\end{array}$ & $\begin{array}{l}\text { Ratio }^{\mathrm{c}} 5 \mathrm{mM} \\
\text { toluene/no toluene }\end{array}$ & $\mathrm{N} / \mathrm{C} / \mathrm{D}^{\mathrm{d}}$ \\
\hline \multicolumn{6}{|l|}{ Energy } \\
\hline PP1755 & FumC-II & Fumarate hydratase, class II & 0.57 & 0.51 & $C^{f}$ \\
\hline PP2112 & AcnA & Aconitate hydratase 1 & 0.61 & 0.47 & $\mathrm{~N}$ \\
\hline PP4050 & GlgA & Glycogen synthase & 0.49 & 0.35 & $C^{f}$ \\
\hline PP4051 & & Alpha-amylase family protein & 0.42 & 0.3 & $C^{f}$ \\
\hline PP4052 & MalQ & 4-Alpha-glucanotransferase & 0.4 & 0.34 & $C^{f}$ \\
\hline PP4053 & & Glycosyl hydrolase, putative & 0.5 & 0.4 & $C^{f}$ \\
\hline PP4055 & $\mathrm{GlgX}$ & Glycogen operon protein $\mathrm{GlgX}$ & 0.52 & 0.39 & $C^{f}$ \\
\hline PP4058 & GlgB & 1,4-Alpha-glucan branching enzyme & 0.61 & 0.42 & $\mathrm{~N}$ \\
\hline PP5007 & & $\begin{array}{l}\text { Polyhydroxyalkanoate granule- } \\
\text { associated protein GA2 }\end{array}$ & 0.6 & 0.49 & $C^{f}$ \\
\hline PP5041 & $\mathrm{GlgP}$ & Glycogen phosphorylase & 0.57 & 0.36 & $\mathrm{~N}$ \\
\hline \multicolumn{6}{|l|}{ Transport } \\
\hline $\mathrm{AF} 183959^{\mathrm{b}}$ & ArpB & $\begin{array}{l}\text { Pseudomonas putida inner membrane } \\
\text { transporter protein }\end{array}$ & 0.49 & 0.47 & $\mathrm{~N}$ \\
\hline $\mathrm{AF} 183959^{\mathrm{b}}$ & ArpA & $\begin{array}{l}\text { Pseudomonas putida periplasmic } \\
\text { linker protein }\end{array}$ & 0.52 & 0.44 & $\mathrm{~N}$ \\
\hline AF183959 ${ }^{b}$ & ArpR & Pseudomonas putida & 0.44 & 0.4 & $\mathrm{~N}$ \\
\hline PP0147 & & Citrate transporter & 0.56 & 0.58 & $\mathrm{~N}$ \\
\hline PP0699 & & Transporter, LysE family & 0.72 & 0.72 & $\mathrm{~N}$ \\
\hline PP0803 & & $\begin{array}{l}\text { Protein secretion } \mathrm{ABC} \text { efflux system, } \\
\text { membrane fusion protein }\end{array}$ & 0.65 & 0.64 & $C^{f}$ \\
\hline PP0804 & & $\begin{array}{l}\text { Protein secretion } \mathrm{ABC} \text { efflux system, } \\
\text { permease and ATP-binding protein }\end{array}$ & 0.35 & 0.39 & $\mathrm{~N}$ \\
\hline PP0805 & & Outer membrane efflux protein & 0.33 & 0.32 & $\mathrm{~N}$ \\
\hline PP0883 & & Porin, putative & 0.41 & 0.33 & $\mathrm{~N}$ \\
\hline PP0884 & & $\begin{array}{l}\text { Dipeptide } \mathrm{ABC} \text { transporter, } \\
\text { periplasmic peptide-binding protein }\end{array}$ & 0.3 & 0.23 & $\mathrm{~N}$ \\
\hline PP0885 & & $\begin{array}{l}\text { Dipeptide } \mathrm{ABC} \text { transporter, } \\
\text { periplasmic peptide-binding protein }\end{array}$ & 0.36 & 0.27 & $C^{f}$ \\
\hline PP1416 & & $\begin{array}{l}\text { Tricarboxylate transport protein TctA, } \\
\text { putative }\end{array}$ & 0.52 & 0.38 & $\mathrm{~N}$ \\
\hline PP1417 & & $\begin{array}{l}\text { Tricarboxylate transport protein TctB, } \\
\text { putative }\end{array}$ & 0.48 & 0.36 & $\mathrm{~N}$ \\
\hline PP1418 & & $\begin{array}{l}\text { Tricarboxylate transport protein } \mathrm{TctC} \text {, } \\
\text { putative }\end{array}$ & 0.42 & 0.34 & $\mathrm{~N}$ \\
\hline PP1419 & & Porin, putative & 0.37 & 0.34 & $\mathrm{~N}$ \\
\hline PP1724 & & $\mathrm{ABC}$ transporter, permease protein & 0.67 & 0.35 & $C^{f}$ \\
\hline PP2092 & NasA & Nitrate transporter & 0.3 & 0.28 & $\mathrm{~N}$ \\
\hline PP2094 & & Nitrate-binding protein NasS, putative & 0.68 & 0.49 & $\mathrm{~N}$ \\
\hline PP2195 & & $\begin{array}{l}\text { Periplasmic polyamine-binding } \\
\text { protein, putative }\end{array}$ & 0.52 & 0.42 & $\mathrm{~N}$ \\
\hline PP2264 & & $\begin{array}{l}\text { Sugar ABC transporter, periplasmic } \\
\text { sugar-binding protein, putative }\end{array}$ & 0.46 & 0.4 & $\mathrm{~N}$ \\
\hline PP2411 & & Major facilitator family transporter & 0.71 & 0.75 & $\mathrm{~N}$ \\
\hline PP3211 & & $\mathrm{ABC}$ transporter, ATP-binding protein & 0.55 & 0.45 & $\mathrm{~N}$ \\
\hline PP3213 & & $\begin{array}{l}\mathrm{ABC} \text { transporter, periplasmic binding } \\
\text { component- related protein }\end{array}$ & 0.82 & 0.59 & $\mathrm{~N}$ \\
\hline PP3635 & & $\begin{array}{l}\text { Sulfonate } \mathrm{ABC} \text { transporter, permease } \\
\text { protein, putative }\end{array}$ & 0.5 & 0.36 & $\mathrm{~N}$ \\
\hline
\end{tabular}


Table 4 continued

\begin{tabular}{|c|c|c|c|c|c|}
\hline Locus tag $^{\mathrm{a}}$ & Gene name & Description $^{\mathrm{e}}$ & $\begin{array}{l}\text { Ratio }^{\mathrm{c}} 3 \mathrm{mM} \\
\text { toluene/no toluene }\end{array}$ & $\begin{array}{l}\text { Ratio }^{\mathrm{c}} 5 \mathrm{mM} \\
\text { toluene/no toluene }\end{array}$ & $\mathrm{N} / \mathrm{C} / \mathrm{D}^{\mathrm{d}}$ \\
\hline PP3636 & & $\begin{array}{l}\text { Sulfonate } \mathrm{ABC} \text { transporter, } \\
\text { periplasmic sulfonate-binding } \\
\text { protein, putative }\end{array}$ & 0.43 & 0.33 & $\mathrm{~N}$ \\
\hline PP3637 & & $\begin{array}{l}\text { Sulfonate ABC transporter, ATP- } \\
\text { binding protein, putative }\end{array}$ & 0.45 & 0.31 & $\mathrm{~N}$ \\
\hline PP3940 & & Major facilitator family transporter & 0.54 & 0.43 & $\mathrm{~N}$ \\
\hline PP3954 & & Periplasmic binding protein, putative & 0.4 & 0.3 & $\mathrm{~N}$ \\
\hline PP4282 & & Aquaporin $\mathrm{Z}$ & 0.48 & 0.43 & $\mathrm{~N}$ \\
\hline PP4309 & & $\begin{array}{l}\text { Transporter, NCS1 nucleoside } \\
\text { transporter family }\end{array}$ & 0.6 & 0.34 & $\mathrm{~N}$ \\
\hline PP4653 & & Transporter, putative & 0.7 & 0.46 & $\mathrm{~N}$ \\
\hline PP5173 & & RND efflux transporter & 0.34 & 0.29 & $\mathrm{~N}$ \\
\hline PP5174 & & $\begin{array}{l}\text { Efflux membrane fusion protein, RND } \\
\text { family }\end{array}$ & 0.53 & 0.45 & $\mathrm{~N}$ \\
\hline PP5207 & & $\begin{array}{l}\mathrm{ABC} \text { transporter, } \mathrm{ATP}-\text { binding protein } \\
\text { permease protein, putative }\end{array}$ & 0.67 & 0.53 & $\mathrm{~N}$ \\
\hline PP5341 & & $\begin{array}{l}\mathrm{ABC} \text { transporter, periplasmic } \\
\text { polyamine-binding protein, putative }\end{array}$ & 0.51 & 0.4 & $\mathrm{~N}$ \\
\hline \multicolumn{6}{|l|}{ Membrane } \\
\hline PP1121 & & OmpA family protein & 0.47 & 0.32 & $C^{f}$ \\
\hline PP1122 & & OmpA family protein & 0.57 & 0.39 & $C^{f}$ \\
\hline PP1408 & PhaG & Acyl-transferase & 0.45 & 0.3 & $\mathrm{~N}$ \\
\hline PP1502 & & OmpA family protein & 0.51 & 0.46 & $\mathrm{~N}$ \\
\hline PP2358 & & $\begin{array}{l}\text { Type } 1 \text { pili subunit CsuA B protein, } \\
\text { putative }\end{array}$ & 0.42 & 0.39 & $C^{f}$ \\
\hline PP2359 & & $\begin{array}{l}\text { Type } 1 \text { pili subunit CsuA B protein, } \\
\text { putative }\end{array}$ & 0.33 & 0.28 & $C^{f}$ \\
\hline PP2360 & & $\begin{array}{l}\text { Type } 1 \text { pili subunit CsuA B protein, } \\
\text { putative }\end{array}$ & 0.28 & 0.21 & $C^{f}$ \\
\hline PP2361 & CsuC & $\begin{array}{l}\text { Type } 1 \text { pili usher pathway chaperone } \\
\text { CsuC }\end{array}$ & 0.39 & 0.31 & $\mathrm{~N}$ \\
\hline PP4361 & FliK & $\begin{array}{l}\text { Flagellar hook-length control protein } \\
\text { FliK }\end{array}$ & 0.66 & 0.48 & $\mathrm{~N}$ \\
\hline PP5081 & & Type IV pili biogenesis protein & 0.76 & 0.67 & $\mathrm{~N}$ \\
\hline \multicolumn{6}{|l|}{ Other } \\
\hline PP3611 & $\operatorname{TrgI}$ & Toluene repressed gene & 0.36 & 0.28 & $\mathrm{C}^{\mathrm{g}}$ \\
\hline PP4010 & $\operatorname{CspD}^{\mathrm{h}}$ & Cold-shock protein CspD & 0.34 & 0.35 & $\mathrm{~N}$ \\
\hline
\end{tabular}

${ }^{\text {a }}$ Locus tag based on genome of $P$. putida KT2440 (http://www.pseudomonas.com)

${ }^{\mathrm{b}}$ NCBI database no

${ }^{c}$ Ratio of expression in 3 or $5 \mathrm{mM}$ toluene versus the absence of toluene

${ }^{d}$ New $(\mathrm{N})$, confirmatory $(\mathrm{C})$, discrepant (D) compared with results in relevant literature

e Description of genes based on locus tag description

${ }^{\mathrm{f}}$ Refers to (Dominguez-Cuevas et al. 2006)

g Refers to (Volkers et al. 2006)

h General stress response gene

The above-mentioned strains were also subjected to a $30-\min 1 \%(\mathrm{v} / \mathrm{v})$ toluene shock. The cells were not preadapted to toluene prior to the shock because trgI expression rapidly decreases after addition of toluene, making adapted wildtype cells phenotypically indistinguishable from $\operatorname{trg} I$-knockout cells as far as $\operatorname{trg} I$-related responses are concerned. Survival frequency was determined by measuring colony-forming units before and after the solvent 
shock treatment. The experiment was repeated six times, as the numbers obtained deviated significantly (not shown). Nonetheless, the survival frequency of S12 $\Delta \operatorname{trgI}$ was consistently higher than that of S12, by a factor ranging from 3 to 8600 . The survival frequency of $\mathrm{S} 12$ was in its turn higher than that of the trgI-overexpression mutant: the mutant showed no survival in four of the six experiments, whereas in the other two the survival frequency was negligibly low. Control cultures with a tetA-insertion in $p y r R$ (PP4997) or the gene encoding a class III aminotransferase (PP5182) did not show an increased tolerance to toluene shock or toluene-induced lysis. Thus, it can be concluded that the tetA gene used to disrupt the $\operatorname{trg} I$ gene does not contribute to the toluene tolerance of the $\operatorname{trgI-knockout}$ mutant.

The improved lysis resistance and solvent shock tolerance of $P$. putida S12 $\Delta \operatorname{trgI}$ suggests a relationship between the $\operatorname{trg} I$ deletion and altered properties of the outer cell structure. As several genes involved in the biosynthesis of the cell wall component peptidoglycan were found to be

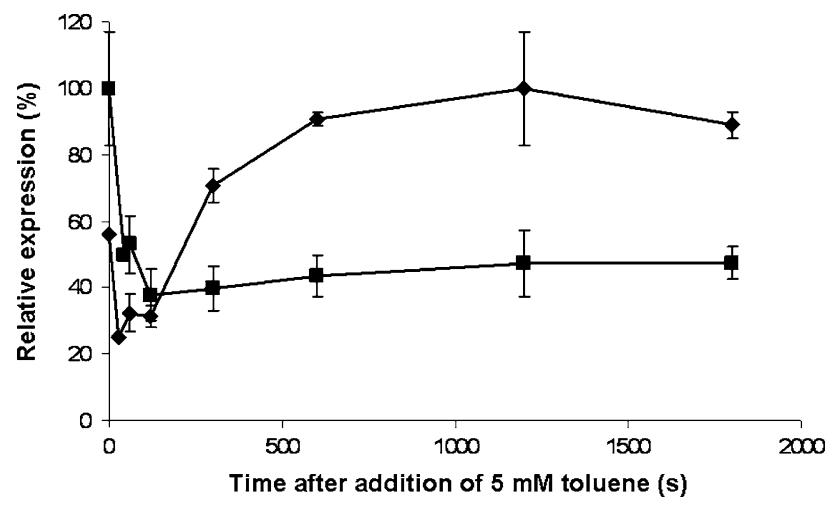

Fig. 2 Relative expression in percentage of the maximum expression of: (squares) trgI and (diamonds) $\operatorname{srpB}$ after addition of $5 \mathrm{mM}$ toluene to an exponentially growing culture of $P$. putida $\mathrm{S} 12$, as determined by qPCR. Values are the average of duplicate experiments (error bars represent deviation from mean) and corrected for experimental variation using expression of KT2440 genes plsB (PP1520) and the putative paaI (PP3281) identified in P. putida S12. For the latter genes no change in expression as response to the presence/absence of toluene in glucose grown chemostat cultures of $P$. putida $\mathrm{S} 12$ was found using transcriptomics analysis. The expression of the genes was defined unchanged before and after addition of $5 \mathrm{mM}$ toluene up-regulated in the presence of toluene, a relationship may exist between the improved lysis resistance of $P$. putida S12 $\Delta$ trgI and peptidoglycan synthesis. Therefore, growth of $P$. putida S12, $P$. putida S12ptrgI and $P$. putida $\mathrm{S} 12 \Delta \operatorname{trgI}$ was investigated in the presence of $\beta$-lactam and other antibiotics (Table 5). P. putida S12 $\Delta \operatorname{trgI}$ showed an increased initial level of resistance against the $\beta$-lactams ampicillin, piperacillin and carbenicillin as compared to $P$. putida $\mathrm{S} 12$. It was less resistant to chloramphenicol and streptomycin. Only slight differences in resistance between the strains were observed for tetracycline, polymyxin B, novobiocin, gentamicin and kanamycin.

In addition to improved $\beta$-lactam resistance, the improved toluene stress tolerance of S12 $\Delta \operatorname{trgI}$ coincided with other effects that may relate to the outer cell structure. Strain S12 $\Delta$ trgI lost the ability to grow in mineral salt medium on glucose or fructose. As the functioning of transport proteins (Bernal et al. 2007) and membrane protein topology (Bogdanov et al. 2002) are known to be affected by membrane composition, the inability to utilize these sugars may be connected to changes in the outer cell structure preventing the sugars from being transported into the cells. The effect appears to be specific as the ability of $\mathrm{S} 12 \Delta \operatorname{trgI}$ to utilize glycerol, succinate or decanol was not affected.

It was found that strain $\mathrm{S} 12 \Delta \operatorname{trg} \mathrm{I}$ could not be transformed with plasmids pJTTtrgI and $\operatorname{pJNNtrgI}(\mathrm{t})$ by electroporation or heat-shock transformation. These methods routinely yield ample transformants with wild-type $\mathrm{S} 12$, demonstrating that the cell envelope of $\mathrm{S} 12 \Delta \operatorname{trgI}$ is difficult to penetrate. Also cell morphology appeared to be affected by the $\operatorname{trg} I$ deletion. Figure 4 shows that stationary-phase wild-type S12 and S12ptrgI have cell shapes quite different from S12 $\Delta$ trgI. Wild-type and S12ptrgI cells are stretched rods with a surface-to-volume ratio of 2.6, whereas the cells of the knock-out mutant are shorter rods with a surface-to-volume ratio of 1.8.

The above observations support the suggestion that the outer cell structure of S12 $\Delta$ trgI differs from that of unadapted wild-type S12, making the cells less permeable and more robust. Since a role of membrane lipids appears obvious, the membrane fatty acid composition was analysed of exponentially growing cells of S12 $\Delta \operatorname{trgI}$ and wild-
Fig. 3 a Pseudomonas putida $\mathrm{S} 12$, b $P$. putida S12ptrgI, and c $P$. putida $\mathrm{S} 12 \Delta \operatorname{trgI}$ after $24 \mathrm{~h}$ of culturing in the presence of $3 \mathrm{mM}$ toluene. Debris of dead cells is deposited onto the wall of the bottles in the cultures of P. putida $\mathrm{S} 12$ and $P$. putida S12ptrgI

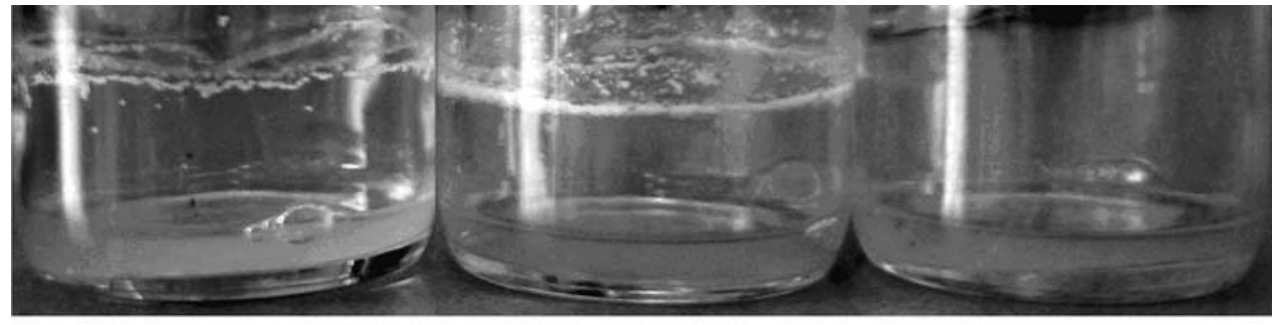

$\begin{array}{lll}\text { A } & \text { B } & \text { C }\end{array}$ 
type S12 cultured in LB medium, either with or without $5 \mathrm{mM}$ toluene. The fatty acid composition changed upon addition of toluene as expected and reported previously (Heipieper and de Bont 1994): the saturation degree as well as the trans:cis ratio of unsaturated fatty acids increased whereas the $\mathrm{C}_{18}: \mathrm{C}_{16}$ ratio decreased (not shown). However, no differences in fatty acid composition were observed between wildtype and $\operatorname{trg} I$ deletion mutant, either or not exposed to toluene.

Table 5 MIC's (mg/L; see "Materials and methods") after 1 day of exposure to various antibiotics of $P$. putida $\mathrm{S} 12, P$. putida $\mathrm{S} 12 \Delta \operatorname{trgI}$ and $P$. putida $\mathrm{S} 12$ ptrgI

\begin{tabular}{|c|c|c|c|}
\hline & $\begin{array}{l}\text { P. putida } \\
\text { S12 }\end{array}$ & $\begin{array}{l}\text { P. putida } \\
\text { S12 trgI }\end{array}$ & $\begin{array}{l}\text { P. putida } \\
\text { S12ptrgI }\end{array}$ \\
\hline Ampicillin & 500 & 1,000 & ND \\
\hline Carbenicillin & 500 & 1,000 & ND \\
\hline Piperacillin & 125 & 750 & ND \\
\hline Chloramphenicol & 500 & 62.5 & 375 \\
\hline Streptomycin & 46.9 & 3.9 & 62.5 \\
\hline Tetracyclin & 23.4 & ND & 31.3 \\
\hline Polymyxin B & 3.9 & 3.9 & 3.9 \\
\hline Novobiocin & 2,000 & 1,000 & 2,000 \\
\hline Gentamycin & 7.8 & 3.9 & ND \\
\hline Kanamycin & 3.9 & 3.9 & 3.9 \\
\hline
\end{tabular}

Values are the average of two experiments. $N D$ not determined because strain possesses tetracyclin or $\beta$-lactam resistance gene
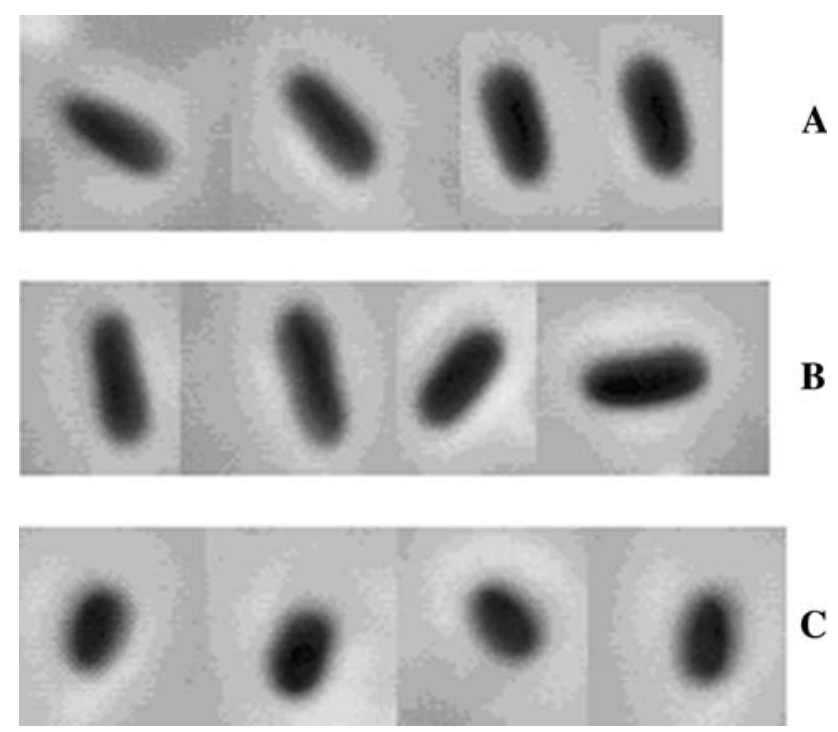

Fig. 4 Typical cells from stationary-phase cultures in the absence of toluene of a $P$. putida S12, b $P$. putida S12ptrgI, c $P$. putida S12 $\Delta$ trgI. Phase-contrast, $\times 100$ magnification, Leitz Aristoplan microscope, Leica DC500 camera

\section{Discussion}

In a previous study, the solvent tolerance responses of $P$. putida $\mathrm{S} 12$ were studied on the proteomic level (Volkers et al. 2006). In the present study, the transcriptional responses to toluene exposure have been investigated. The two studies should be regarded as complementary, as it has proven difficult to compare proteomics and transcriptomics directly (Hegde et al. 2003), both for technical (e.g. pI range and solubility of proteins) and fundamental reasons (protein expression is not only regulated at the transcriptional level).

The transcriptional responses of $P$. putida $\mathrm{S} 12$ to toluene could be categorized into three types: (1) responses that can be directly connected to (known) solvent tolerance mechanisms; (2) responses related to the increased energy demand brought about by the solvent; (3) responses of which the relationship with the presence of solvent is not immediately clear. From the viewpoint of global transcription responses, toluene stress has a relatively small impact as compared to the differential gene expression that is invoked by switching between carbon and nitrogen limitation. This is in agreement with earlier observations in S. cerevisiae (Boer et al. 2003; Fujita et al. 2004) and E. coli (Hua et al. 2004). The relatively weak effect on the global transcription level, however, is no measure of the seriousness of the impact that toluene may have on the physiological level. The effect of toluene on differential expression of general stress response genes is nevertheless relatively small. It should be noted that steady-state chemostat cultures were studied, which implies that the adaptational machinery to toluene is fully induced. Apparently, this machinery is of such a high efficiency that the stress sensed by the cells is below the trigger threshold of general stress responses. Segura et al. (2005) found a heat-shock response in batch-cultured $P$. putida DOT-T1E, which was absent in chemostat-cultured $P$. putida S12. It may be argued that batch-cultured cells of $P$. putida DOTT1E experience more or a different form of stress from toluene than chemostat cultured $P$. putida $\mathrm{S} 12$ cells, which are at steady state and, thus, fully adapted to the presence of a constant concentration of toluene.

Responses connected to toluene tolerance mechanisms

The up-regulation of the solvent pump $\operatorname{srp} A B C$ and its presumed regulators $\operatorname{srpRS}$ is an expected response directly linked to a well-known toluene tolerance mechanism. The up-regulation of $\operatorname{srp} R S$ appears to contradict the finding by Wery et al. (2001) that SrpS and SrpR are repressors of $s r p A B C$. However, if SrpR, in analogy to the $t t g G H I$ regulator $\mathrm{TtgV}$ in P. putida DOT-T1E (Fujita et al. 2004) (96\% identical to SrpR), is released from its operator site 
by a toluene-trigger, transcription of both $\operatorname{srp} A B C$ and $\operatorname{srpRS}$ may be initiated at the same time.

Also the up-regulation of genes involved in peptidoglycan biosynthesis (transglycosylase (PP1036), penicillinbinding protein (PP5084), $N$-acetylmuramoyl-L-alanine amidase (PP4897) and membrane-bound lytic murein transglycosylase B (mltB, PP4805)) (Mostertz et al. 2004), may be regarded as a specific toluene resistance response. The effect of toluene on cell morphology, i.e. an increased cell diameter under solvent stress (Neumann et al. 2005), may invoke increased turnover of peptidoglycan which must be compensated by the upregulation of peptidoglycan synthesis. Also solvent-induced damage of the peptidoglycan layer may be a reason for the upregulation observed.

Responses relating to the energy status of the cell

The biomass yield was negatively affected by the presence of toluene as observed previously (Isken et al. 1999; Volkers et al. 2006): at $3 \mathrm{mM}$ toluene, the biomass yield dropped by $\sim 50 \%$ compared to cultures without toluene, but no change in biomass yield was observed between 3 and $5 \mathrm{mM}$ toluene. Interestingly, the expression levels of the genes encoding the solvent resistance pump srpABC followed a reciprocal trend: $\operatorname{srp} A B C$ levels were tenfold increased in $3 \mathrm{mM}$ compared to $0 \mathrm{mM}$ toluene, and levels remained equally high at 3 and $5 \mathrm{mM}$ toluene. Equal levels of $\operatorname{srp} A B C$ mRNA are expected to yield equal levels of active pump, resulting in an equal metabolic burden brought about by the energy demand of SrpABC-mediated, PMF-driven toluene extrusion. This observation provides an indication that energy consumption by SrpABC is the major cause of the yield loss in the presence of toluene.

Numerous transcriptional responses were observed that are in agreement with an increased energy demand in the presence of toluene. The up-regulation of gluconate and 2-keto-gluconate kinases and transporters, via which glucose is channelled to the Entner-Doudoroff pathway, is indicative of a higher glucose consumption rate. The inability of the $\operatorname{trgI-knock-out~strain~to~grow~on~glucose~and~fructose~can~be~}$ explained by $\operatorname{trgI}$ not being expressed at all in this strain, whereas in the wild-type it is only down-regulated to $35 \%$ of the non-stressed expression level in $3 \mathrm{mM}$ toluene and to $28 \%$ in $5 \mathrm{mM}$ toluene. Also, changes in the outer cell structure of S12 $\Delta \operatorname{trgI}$ may influence the functioning of the proteins involved in transport of glucose and fructose (Bogdanov et al. 2002; Bernal et al. 2007).

In agreement with the up-regulation of the gluconate and 2-keto-gluconate kinases and transporters, several genes involved in sugar storage were down-regulated. A TCA cycle gene was up-regulated, as were genes for respiratory chain elements such as several subunits of NADH dehydrogenase. These responses are envisaged to enable the cells to compensate for the loss of energy invoked by toluene exposure.

Also, a large group of transport systems were downregulated. Down-regulation of these transport systems may be related to further energy saving, as suggested in our recent proteomics analysis (Volkers et al. 2006). Downregulation of transporters may also decrease the number of possibilities for toluene molecules to enter the cell. The hypothesis of general energy saving may also apply to other down-regulated genes which have no direct relation to solvent stress. The overall group of down-regulated genes is larger than the up-regulated genes and the level of expression of most down-regulated genes is inversely proportional to the concentration of toluene.

Responses that have an indirect relationship with toluene tolerance

In the presence of toluene, genes encoding three flagellar structural proteins, a flagellar export component and a flagella basal body subunit were up-regulated. The gene coding for the flagellar hook-length protein was downregulated. A relationship between flagella and solvent tolerance has been reported previously in solvent-tolerant P. putida strains (Kieboom et al. 2001; Segura et al. 2001; Dominguez-Cuevas et al. 2006). In each case, different flagella genes were found to influence solvent tolerance. Our findings confirm the existence of a link between flagella and solvent tolerance, but its nature remains to be elucidated and may be found at the regulatory level (Kieboom et al. 2001; Ramos et al. 2002). However, a direct relationship between flagellar systems and toluene tolerance could exist if the flagellar export system is able to export toluene molecules as well.

\section{$\operatorname{TrgI}$, a novel solvent-tolerance-related gene}

Both in the present transcriptomics and our previous proteomics study a strong down-regulation of the hypothetical gene trgI (P. putida KT2240-locus PP3611) was observed. In addition, it was demonstrated that $\operatorname{trg} I$ is downregulated immediately upon exposure to toluene. This observation explains the poor reproducibility of the toluene shock experiments. The momentaneous downregulation of $\operatorname{trg} I$ compromises the discrimination between the phenotypes of toluene-exposed wild-type $\mathrm{S} 12$ and the $\operatorname{trg} I$-knockout strain. The extremely low survival frequency of the $\operatorname{trg} I$ overexpression mutant stresses the importance of downregulation of the gene for solvent tolerance. The fast response of $\operatorname{trgI}$ suggests a role in initial solvent stress response. As toluene dissolves in the $\mathrm{S} 12$ membrane at a high rate reaching the maximum concentration within 
10 min (Neumann et al. 2005), mechanisms conferring toluene tolerance at a short time scale are a prerequisite for the cells to switch on the toluene extrusion pump SrpABC. This pump is crucial for survival in the presence of toluene, but $s r p$-promoter driven LacZ expression has been shown not to start until over $2 \mathrm{~h}$ after toluene exposure (Kieboom et al. 1998b). The expression profile of $\operatorname{srpB}$ obtained in the present study confirmed that $\operatorname{srp} A B C$ expression is a late response. The fast down-regulation of $\operatorname{trg} I$ suggests a role in such a first line of defence against toluene.

It was demonstrated that the $\operatorname{trgI-knockout~has~altered~}$ cell morphology and altered level of resistance against antibiotics. In addition, the trgI knockout strain is incapable of utilizing glucose and fructose and is more resistant to toluene-induced lysis. These observations strongly suggest an effect of $\operatorname{trgI}$ on the outer cell structure. An influence of $\operatorname{trgI}$ on fatty acid composition is unlikely since the fatty acid composition of $P$. putida S12, either or not exposed to toluene, was not affected by the trgI deletion. Still, preliminary indications were found that the phospholipid headgroup composition may be affected by the trgI deletion, most notably resulting in an increased cardiolipin content (unpublished).

\section{Conclusion}

The present study presents important new and additional information concerning transcriptional responses of solvent tolerant $P$. putida to solvent exposure. Several new groups of differentially expressed genes have been revealed that have not been linked previously to toluene tolerance, such as the gluconate and 2-ketogluconate kinase and transporter genes and the genes involved in biosynthesis of the peptidoglycan layer. Importantly, a combined transcriptomic and proteomic approach (Hartmans et al. 1989; Segura et al. 2005) revealed the interplay between specific responses (e.g. solvent resistance pump SrpABC) and global compensatory responses (e.g. TCA cycle), as well as previously unknown functions. The discovery of the new solvent tolerance gene $\operatorname{trgI}$ has provided an important new piece of information that will help to solve the puzzle of solvent tolerance.

Acknowledgment This research was funded by the Kluyver Centre for Genomics of Industrial Fermentation, which is supported by the Netherlands Genomics Inititative (NGI).

\section{References}

Alekshun MN, Levy SB (1999) The mar regulon: multiple resistance to antibiotics and other toxic chemicals. Trends Microbiol $7: 410-413$
Ballerstedt H, Volkers RJM, Mars AE, Hallsworth JE, Martins dos Santos VA, Puchalka J et al (2007) Genomotyping of Pseudomons putida strains using $P$. putida KT2440-based high-density DNA microarrays: implications for transcriptomics studies. Appl Microbiol Biotechnol 75:1133-1142

Bernal P, Munoz-Rojas J, Hurtado A, Ramos JL, Segura A (2007) A Pseudomonas putida cardiolipin synthesis mutant exhibits increased sensitivity to drugs related to transport functionality. Environ Microbiol 9:1135-1145

Boer VM, de Winde JH, Pronk JT, Piper MD (2003) The genome-wide transcriptional responses of Saccharomyces cerevisiae grown on glucose in aerobic chemostat cultures limited for carbon, nitrogen, phosphorus, or sulfur. J Biol Chem 278:3265-3274

Bogdanov M, Heacock PN, Dowhan W (2002) A polytopic membrane protein displays a reversible topology dependent on membrane lipid composition. Embo J 21:2107-2116

Brown SD, Thompson MR, Verberkmoes NC, Chourey K, Shah M, Zhou J et al (2006) Molecular dynamics of the Shewanella oneidensis response to chromate stress. Mol Cell Proteomics 5:1045-1071

Budde I, Steil L, Scharf C, Volker U, Bremer E (2006) Adaptation of Bacillus subtilis to growth at low temperature: a combined transcriptomic and proteomic appraisal. Microbiology 152:831853

Dominguez-Cuevas P, Gonzalez-Pastor JE, Marques S, Ramos JL, de Lorenzo V (2006) Transcriptional tradeoff between metabolic and stress-response programs in Pseudomonas putida KT2440 cells exposed to toluene. J Biol Chem 281:11981-11991

Fujita K, Matsuyama A, Kobayashi Y, Iwahashi H (2004) Comprehensive gene expression analysis of the response to straightchain alcohols in Saccharomyces cerevisiae using cDNA microarray. J Appl Microbiol 97:57-67

Griffin TJ, Gygi SP, Ideker T, Rist B, Eng J, Hood L, Aebersold R (2002) Complementary profiling of gene expression at the transcriptome and proteome levels in Saccharomyces cerevisiae. Mol Cell Proteomics 1:323-333

Hartmans S, Smits J, van de Werf M, Volkering F, de Bont J (1989) Metabolism of styrene oxide and 2-phenyl ethanol in the styrene degrading Xanthobacter strain 124X. Appl Environ Microbiol 55:2850-2855

Hartmans S, van der Werf MJ, de Bont JAM (1990) Bacterial degradation of styrene involving a novel flavin adenine dinucleotide-dependent styrene monooxygenase. Appl Environ Microbiol 56:1347-1351

Hayashi S, Aono R, Hanai T, Mori H, Kobayashi T, Honda H (2003) Analysis of organic solvent tolerance in Escherichia coli using gene expression profiles from DNA microarrays. J Biosci Bioeng 95:379-383

Hegde PS, White IR, Debouck C (2003) Interplay of transcriptomics and proteomics. Curr Opin Biotechnol 14:647-651

Heipieper HJ, de Bont JAM (1994) Adaptation of Pseudomonas putida S12 to ethanol and toluene at the level of fatty acid composition of membranes. Appl Environ Microbiol 60:4440 4444

Hua Q, Yang C, Oshima T, Mori H, Shimizu K (2004) Analysis of gene expression in Escherichia coli in response to changes of growth-limiting nutrient in chemostat cultures. Appl Environ Microbiol 70:2354-2366

Isken S, de Bont JAM (1998) Bacteria tolerant to organic solvents. Extremophiles 2:229-238

Isken S, Derks A, Wolffs PFF, de Bont JAM (1999) Effect of organic solvents on the yield of solvent-tolerant Pseudomonas putida S12. Appl Environ Microbiol 65:2631-2635

Kieboom J, de Bont JAM (2000) Mechanisms of organic solvent tolerance in bacteria. In: Storz G, Hengge-Aronis R (eds) Bacterial stress responses. ASM press, Washington, pp 393-402 
Kieboom J, Dennis JJ, Zylstra G, de Bont JAM (1998a) Active efflux of organic solvents by Pseudomonas putida S12 is induced by solvents. J Bacteriol 180:6769-6772

Kieboom J, Dennis JJ, de Bont JAM, Zylstra G (1998b) Identification and molecular characterization of an efflux pump involved in Pseudomonas putida $\mathrm{S} 12$ solvent tolerance. J Biol Chem 273:85-91

Kieboom J, Bruinenberg R, Keizer-Gunnink I, de Bont JAM (2001) Transposon mutations in the flagella biosynthetic pathway of the solvent-tolerant Pseudomonas putida S12 result in a decreased expression of solvent efflux genes. FEMS Microbiol Lett 198:117-122

Kobayashi H, Takami H, Hirayama H, Kobata K, Usami R, Horikoshi K (1999) Outer membrane changes in a toluene-sensitive mutant of toluene-tolerant Pseudomonas putida IH-2000. J Bacteriol 181:4493-4498

Letunic I, Copley RR, Pils B, Pinkert S, Schultz J, Bork P (2006) SMART 5: domains in the context of genomes and networks. Nucleic Acids Res 34:D257-D260

Matsui K, Hirayama T, Kuroda K, Shirahige K, Ashikari T, Ueda M (2006) Screening for candidate genes involved in tolerance to organic solvents in yeast. Appl Microbiol Biotechnol 71:75-79

Mostertz J, Scharf C, Hecker M, Homuth G (2004) Transcriptome and proteome analysis of Bacillus subtilis gene expression in response to superoxide and peroxide stress. Microbiology 150:497-512

Neumann G, Veeranagouda Y, Karegoudar TB, Sahin O, Mausezahl I, Kabelitz N et al (2005) Cells of Pseudomonas putida and Enterobacter $\mathrm{sp}$. adapt to toxic organic compounds by increasing their size. Extremophiles 9:163-168

Nijkamp K, van Luijk N, de Bont JA, Wery J (2005) The solventtolerant Pseudomonas putida S12 as host for the production of cinnamic acid from glucose. Appl Microbiol Biotechnol 69:170177

Nijkamp K, Westerhof RG, Ballerstedt H, de Bont JA, Wery J (2007) Optimization of the solvent-tolerant Pseudomonas putida S12 as host for the production of p-coumarate from glucose. Appl Microbiol Biotechnol 74:617-624

Quandt J, Hynes MF (1993) Versatile suicide vectors which allow direct selection for gene replacement in gram-negative bacteria. Gene 127:15-21

Ramos JL, Duque E, Rodriguez-Herva J-J, Godoy P, Haidour A, Reyes F, Fernandez-Barrero A (1997) Mechanisms for solvent tolerance in bacteria. J Biol Chem 272:3887-3890
Ramos JL, Duque E, Gallegos MT, Godoy P, Ramos-Gonzalez MI, Rojas A et al (2002) Mechanisms of solvent tolerance in gramnegative bacteria. Ann Rev Microbiol 56:743-768

Sambrook J, Fritsch EF, Maniatis T (1982) Molecular cloning: a laboratory manual. Cold Spring Harbour Press, Cold Spring Harbour

Schultz J, Milpetz F, Bork P, Ponting CP (1998) SMART, a simple modular architecture research tool: identification of signaling domains. Proc Natl Acad Sci USA 95:5857-5864

Segura A, Duque E, Hurtado A, Ramos JL (2001) Mutations in genes involved in the flagellar export apparatus of the solvent-tolerant Pseudomonas putida DOT-T1E strain impair motility and lead to hypersensitivity to toluene shocks. J Bacteriol 183:4127-4133

Segura A, Godoy P, van Dillewijn P, Hurtado A, Arroyo N, Santacruz S, Ramos JL (2005) Proteomic analysis reveals the participation of energy- and stress-related proteins in the response of Pseudomonas putida DOT-T1E to toluene. J Bacteriol 187:5937-5945

Sikkema J, de Bont JAM, Poolman B (1995) Mechanisms of membrane toxicity of hydrocarbons. Microbiol Rev 59:201-222

Volkers RJM, de Jong AL, Hulst AG, van Baar BLM, de Bont JAM, Wery J (2006) Chemostat-based proteomic analysis of tolueneaffected Pseudomonas putida S12. Environ Microbiol 8:16741679

Weber FJ, de Bont JAM (1996) Adaptation mechanisms of microorganisms to the toxic effects of organic solvents on membranes. Biochim Biophys Ac 1286:228-245

Wery J, Hidayat B, Kieboom J, de Bont JAM (2001) An insertion sequence prepares Pseudomonas putida S12 for severe solvent stress. J Biol Chem 276:5700-5706

Wierckx JPN, Ballerstedt H, de Bont JAM, de Winde JH, Ruijssenaars H, Wery J (2008) Transcriptome analysis of a phenolproducing Pseudomonas putida S12 construct: genetic and physiological basis for improved production. J Bacteriol 190:2822-2830

Wu J, Zhang N, Hayes A, Panoutsopoulou K, Oliver SG (2004) Global analysis of nutrient control of gene expression in Saccharomyces cerevisiae during growth and starvation. Proc Natl Acad Sci USA 101:3148-3153 